\title{
The Influence of 1 $\alpha .25$-Dihydroxyvitamin D3 Coating on Implant Osseointegration in the Rabbit Tibia
}

\author{
Yoshihito Naito $^{1,2}$, Ryo Jimbo ${ }^{1,3}$, Matthew S. Bryington ${ }^{4}$, Stefan Vandeweghe ${ }^{5}$, Bruno R. Chrcanovic ${ }^{1}$, \\ Nick Tovar ${ }^{6}$, Tetsuo Ichikawa ${ }^{2}$, Paulo G. Coelho ${ }^{6}$, Ann Wennerberg ${ }^{1}$ \\ ${ }^{1}$ Department of Prosthodontics, Faculty of Odontology, Malmö University, Malmö, Sweden. \\ ${ }^{2}$ Department of Oral and Maxillofacial Prosthodontics and Oral Implantology, Institute of Health Biosciences, The University \\ of Tokushima Graduate School, Tokushima, Japan. \\ ${ }^{3}$ Department of Applied Prosthodontics, Graduate School of Biomedical Sciences, Nagasaki University, Nagasaki, Japan. \\ ${ }^{4}$ Department of Restorative Dentistry, West Virginia University School of Dentistry, Morgantown, West Virginia, USA. \\ ${ }^{5}$ Department of Periodontology and Oral Implantology, Dental School, Faculty of Medicine and Health sciences, University \\ of Ghent, Belgium. \\ ${ }^{6}$ Department of Biomaterials and Biomimetics, New York University, New York, USA.
}

\author{
Corresponding Author: \\ Yoshihito Naito \\ Department of Prosthodontics, Faculty of Odontology \\ Malmö University \\ 20506 Malmö \\ Sweden \\ Phone: +46 406658679 \\ Fax: + 46406658503 \\ E-mail: yoshi11@tokushima-u.ac.jp
}

\section{ABSTRACT}

Objectives: This study aims to evaluate bone response to an implant surface modified by 1 1 2,25 -dihydroxyvitamin $\mathrm{D} 3\left[1.25-(\mathrm{OH})_{2} \mathrm{D}_{3}\right]$ in vivo and the potential link between $1.25-(\mathrm{OH})_{2} \mathrm{D}_{3}$ surface concentration and bone response.

Material and Methods: Twenty-eight implants were divided into 4 groups (1 uncoated control, 3 groups coated with $1.25-(\mathrm{OH})_{2} \mathrm{D}_{3}$ in concentrations of $10^{-8}, 10^{-7}$ and $10^{-6} \mathrm{M}$ respectively), placed in the rabbit tibia for 6 weeks. Topographical analyses were carried out on coated and uncoated discs using interferometer and atomic-force-microscope (AFM). Twentyeight implants were histologically observed (bone-to-implant-contact [BIC] and new-bone-area [NBA]).

Results: The results showed that the $1.25-(\mathrm{OH})_{2} \mathrm{D}_{3}$ coated implants presented a tendency to osseointegrate better than the noncoated surfaces, the differences were not significant $(\mathrm{P}>0.05)$.

Conclusions: The effect of 1.25- $(\mathrm{OH})_{2} \mathrm{D}_{3}$ coating to implants suggested possible dose dependent effects, however no statistical differences could be found. It is thought that the base substrate topography (turned) could not sustain sufficient amount of $1.25-(\mathrm{OH})_{2} \mathrm{D}_{3}$ enough to present significant biologic responses. Thus, development a base substrate that can sustain $1.25-(\mathrm{OH})_{2} \mathrm{D}_{3}$ for a long period is necessary in future studies.

Keywords: dental implants; vitamin D; drug dose response relationship; histological techniques; bone formation.

\section{Accepted for publication: 19 August 2014}

To cite this article:

Naito Y, Jimbo R, Bryington MS, Vandeweghe S, Chrcanovic BR, Tovar N, Ichikawa T, Coelho PG, Wennerberg A. The Influence of $1 \alpha .25$-Dihydroxyvitamin D3 Coating on Implant Osseointegration in the Rabbit Tibia.

J Oral Maxillofac Res 2014;5(3):e3

URL: http://www.ejomr.org/JOMR/archives/2014/3/e3/v5n3e3ht.pdf

doi: $10.5037 /$ jomr.2014.5303 


\section{INTRODUCTION}

Implant surface features plays a key role in the quality and rate of osseointegration [1]. Recent investigations have reported that along with the surface topographical modifications, the application of bioactive agents may result in enhanced osteogenic properties to the implant surface [2-4]. Bioactive implants have been reported to possibly develop a biochemical bonding between the bone tissue and the titanium implant surface rather than a merely physical one [ $[\underline{6}, \underline{6}]$. A bioactive implant surface is defined as one that has the potential to promote numerous molecular interactions, potentially forming a chemical bond between bone and implant surface []. Previous studies have demonstrated that proteins or peptides with bioactive capacity such as bone morphogenetic proteins (BMPs), fibronectin, type I collagen, fibroblast growth factor (FGF), and arginine-glycineaspartic acid (RDG-peptide) are promising bioactive molecular candidates with a high osteogenic potential [7-9]. However, their fabrication and economic feasibility along with technical and regulatory issues have led researchers to explore alternative bioactive molecules such as the bone mobilizing hormone vitamin D.

Vitamin D has been shown to play an essential role in bone mineral homeostasis and in its active form, $1 \alpha, 25$-dihydroxyvitamin $\mathrm{D} 3\left[1.25-(\mathrm{OH})_{2} \mathrm{D}_{3}\right]$, may act as a bioactive protein promoting new bone formation $[10,11]$. The most important role of $1 \cdot 25-(\mathrm{OH})_{2} \mathrm{D}_{3}$ is that it regulates the intestinal adsorption of calcium and phosphate, resulting in increased plasma concentrations [12]. However, to date, the exact role of $1.25-(\mathrm{OH})_{2} \mathrm{D}_{3}$ in osteogenesis has yet to be fully explored since the hormone effects multiple cellular pathways $[\underline{13}, \underline{14}]$.

Previous studies have reported that $1.25-(\mathrm{OH})_{2} \mathrm{D}_{3}$ significantly promoted the expression of osteogenic markers, in addition, $1.25-(\mathrm{OH})_{2} \mathrm{D}_{3}$ deficiency negatively impacts osseointegration $[\underline{15}, \underline{16}]$. It has been suggested that $1.25-(\mathrm{OH})_{2} \mathrm{D}_{3}$ has a direct effect on osteogenesis since vitamin D receptors (VDR) are present on osteoblasts and osteoclast precursors, with activation leading to RANKL expression $[17, \underline{18}]$. Masuyama et al. [16] reported in their in vivo study using mice that $1.25-(\mathrm{OH})_{2} \mathrm{D}_{3}$ exerted a regulatory effect on osteoblast and osteoclast chemotaxis during increasing vascular tissue infiltration. Furthermore, Masuyama et al. [16] showed that 1.25-(OH) ${ }_{2} \mathrm{D}_{3}$ could regulate collagen modification and maturation in an osteoblastic cell culture, which has been proven to be important in early bone formation [19].
Numerous studies have also suggested that these intriguing osteogenic influences of $1.25-(\mathrm{OH})_{2} \mathrm{D}_{3}$ are dose dependent $[17, \underline{20}, \underline{21}]$.

Even though previous in vitro studies of $1.25-(\mathrm{OH})_{2} \mathrm{D}_{3}$ suggest its promising effects on osteogenesis, the in vivo biologic responses have not yet been confirmed especially when attached to implantable materials. The aim of this study was to histologically evaluate the osteogenic effect of $1.25-(\mathrm{OH})_{2} \mathrm{D}_{3}$ coatings to endosteal implant surfaces and to determine if the biologic response would be doses dependent of $1.25-(\mathrm{OH})_{2} \mathrm{D}_{3}$ concentration on the surface.

\section{MATERIAL AND METHODS Surface preparations}

Twenty-eight commercially pure machine turned titanium implants (Grade 4, Neodent ${ }^{\circledR}$ Curitiba, Brazil), $7 \mathrm{~mm}$ in length and $3.75 \mathrm{~mm}$ in diameter were used in this study. The implants were divided into 4 groups with 7 implants in each group, with one functioning as an uncoated control group. The remaining groups were coated with $1.25-(\mathrm{OH})_{2} \mathrm{D}_{3}$ in concentrations of $10^{-8}, 10^{-7}$ and $10^{-6} \mathrm{M}$ respectively, based on a previous in vitro investigation [18]. $1.25-(\mathrm{OH})_{2} \mathrm{D}_{3}$ was diluted in $\geq 99.5 \%$ ethanol until desired concentrations were achieved. The implants were soaked in the respective solution for $1 \mathrm{~h}$ and thereafter were gently rinsed with phosphate buffered saline (Invitrogen, GIBCO, Sweden) and finally were air-dried in a 24-well plate. The well was covered with lab-foil and stored in a freezer prior to surgery. For topographical investigation, 3 discs $(8 \mathrm{~mm}$ in diameter, $1 \mathrm{~mm}$ in thickness) of turned commercially pure titanium (grade 4) were soaked in each solution (a total of 9 discs) following the same procedure as when soaking the implants.

\section{Topographic analysis}

An optical interferometer (MicroXam; ADE Phase Shift Technology, Inc., Tucson, AZ) was used to characterize the topography of 3 uncoated implants. All twelve discs were also measured with interferometer at 3 randomly selected sites and thereafter topographically compared to each other. The following topographical parameters were used: $\mathrm{S}_{\mathrm{a}}(\mu \mathrm{m})=$ average height deviation from a mean plane, $\mathrm{S}_{\mathrm{ds}}\left(\mu \mathrm{m}^{-2}\right)=$ density of summits and $\mathrm{S}_{\mathrm{dr}}(\%)=$ developed surface ratio [22]. Before the parametrical calculation could be evaluated, the waviness from the surface was removed using a $50 \times 50 \mu \mathrm{m}$ Gaussian filter. For each selected scan area, the mean value 
and standard deviation of the parameters were obtained from 9 scans of each group (a total of thirtysix measurements), from random sites on the surface. In order to obtain the surface roughness in the nanometer length scale, atomic-force-microscopy (AFM, XE-100, Park Systems Corp, Suwon, Korea) was utilized on the same twelve discs. For the measurements, 3 different scanning areas were selected $(10 \times 10 \mu \mathrm{m}, 5 \times 5 \mu \mathrm{m}$ and $1 \times 1 \mu \mathrm{m})$. The images obtained by AFM were subjected to levelling and applied Gaussian filtering with a cut-off of $2.5 \mu \mathrm{m}$ (for $10 \times 10 \mu \mathrm{m}$ scans), $1 \mu \mathrm{m}$ (for $5 \times 5 \mu \mathrm{m}$ scans), and $0.25 \mu \mathrm{m}$ (for $1 \times 1 \mu \mathrm{m}$ scans), using the software MontainsMap 6 (Digital Surf, Besançon, France) and the same three-dimensional parameters used for the interferometer $\left(\mathrm{S}_{\mathrm{a}}, \mathrm{S}_{\mathrm{dr}}, \mathrm{S}_{\mathrm{ds}}\right)$ were evaluated to correlate to the micro roughness. For each selected scan area, the mean value and standard deviation of the parameters were obtained from 9 scans of each group (a total of thirty-six measurements), from random sites on the surface.

\section{Animal preparation}

Twelve New Zealand white rabbits (mean body weight $4.7 \mathrm{~kg}$ [range $3.8-5.2 \mathrm{~kg}$ ]) were used in this study. The study was approved by the Ethics Committee for Animal Research at the École Nationale Vétérinaire d'Alfort (Maisons-Alfort, Val-de-Marne, France). All surgical procedures were performed under general anaesthesia. The pre-anaesthetic procedure comprised an intra-muscular administration of atropine sulfate $(0.044 \mathrm{mg} / \mathrm{kg})$ and xylazine chlorate $(8 \mathrm{mg} / \mathrm{kg})$. General anaesthesia was then obtained following an intra-muscular injection of ketamine chlorate (15 $\mathrm{mg} / \mathrm{kg}$ ). Thereafter, the hind legs were shaved and disinfected with iodine solution. After anaesthetic and disinfection procedures, the proximal tibiae on both sides were exposed and 4 osteotomy sites ( 2 in each leg) were prepared according to the manufacturer's instructions for placement of implants in dense bone, i.e., to avoid excessive torque.

\section{Histological preparation and analyses}

After 6 weeks of healing, the animals were euthanized with anaesthesia overdose and the implants were removed en bloc and thereafter were placed in $4 \%$ formaldehyde for $24 \mathrm{~h}$. After fixation, the samples were subjected to dehydration in a series of ethanol $(70-100 \%)$ and infiltration in resin (30 - 100\%) under constant vacuuming and thereafter were embedded in light curing-resin (Technovit 7200 VLC; Heraeus Kulzer, Wehrheim, Germany). The embedded resin blocks were subjected to non-decalcified cut and grind sectioning. In brief, a central section of each sample were prepared using the EXAKT ${ }^{\mathrm{TM}}$ cutting and grinding equipment to a final thickness of $15 \mu \mathrm{m}$. After polishing to exclude scratches, the sections were finally stained with a mixed solution of toluidine blue and pyronin $\mathrm{G}$.

The histological analyses were performed using a light microscope (Eclipse ME600; Nikon, Japan) and the histomorphological data was analyzed with image analysis software (Image J v. 1.43u; National Institute of Health). Calculation of bone-to-implant contact (BIC) ratio along the implants surfaces and new-bone-area (NBA) within the threads were made using a x10 magnification objective. Histology and histomorphometry were both conducted in a blind manner.

\section{Statistical analysis}

The statistical analyses of the mean values of the discs topography were composed and compared using One-Way Analysis of Variance (ANOVA). The statistical significance level was set at $\mathrm{P} \leq 0.05$. Histological multiple group comparisons were performed by computer software SPSS for Macintosh (SPSS Inc., Chicago, IL, USA). The results from the histomorphometric measurements were expressed as means and standard deviations (M [SD]). The different treatment groups were compared using Kruskal Wallis with the significance level set at $P \leq 0.05$.

\section{RESULTS \\ Topographical analyses}

Topographical analyses of the discs with the interferometer showed a statistical significant difference $(\mathrm{P}=0.049)$ regarding the density of summits in $\mu \mathrm{m}^{-2}\left(\mathrm{~S}_{\mathrm{ds}}\right)$, as presented in Table 1 .

Table 1. Mean values for $\mathrm{S}_{\mathrm{a}}, \mathrm{S}_{\mathrm{dr}}, \mathrm{S}_{\mathrm{ds}}$ (standard deviation) for topographical analyses of discs with interferometer and P-values for one-way ANOVA comparisons

\begin{tabular}{c|c|c|c|c}
\hline $\begin{array}{c}\text { Concentration of } \\
\mathbf{1 . 2 5}-(\mathbf{O H})_{\mathbf{2}} \mathbf{D}_{\mathbf{3}}(\mathbf{M})\end{array}$ & $\mathbf{S}_{\mathrm{a}}(\boldsymbol{\mu \mathbf { m } )}$ & $\mathbf{S}_{\mathrm{dr}}(\mathbf{\%})$ & $\mathbf{S}_{\mathrm{ds}}\left(\mathbf{1} / \boldsymbol{\mu m}^{2}\right)$ & Quantity \\
\hline $\mathbf{0}$ & $0.3(0.02)$ & $6(0.1)$ & $129339(1374)$ & 3 \\
\hline $\mathbf{1 0}^{-8}$ & $0.3(0.03)$ & $8.1(1.8)$ & $143980.5(4187.4)$ & 3 \\
\hline $\mathbf{1 0}^{-7}$ & $0.3(0.06)$ & $5.5(1.3)$ & $131965.2(4142.4)$ & 3 \\
\hline $\mathbf{1 0}^{-6}$ & $0.3(0.07)$ & $5.9(1.3)$ & $131705.8(9496.7)$ & 3 \\
\hline P-value & 0.503 & 0.074 & 0.049 & \\
\hline
\end{tabular}


The 1.25- $(\mathrm{OH})_{2} \mathrm{D}_{3}$ coating did not yield any significant differences in surface topography parameters in the micro level for the average height derivation in $\mu \mathrm{m}$ $\left(\mathrm{S}_{\mathrm{a}}\right)$ or for the developed surface ratio in $\%\left(\mathrm{~S}_{\mathrm{dr}}\right)$ (both dependent variables at $\mathrm{P}>0.05$ ).

Topographical analyses in the nanometer level with AFM showed no significant differences $(\mathrm{P}>0.05)$ between all groups tested (Table 2 - 4).
The descriptive images for both interferometer and AFM are presented in Figure 1. The investigation of samples by interferometer showed no qualitative differences in the morphology of the surface between the control and test groups. The image scans obtained from AFM also showed no qualitatively distinct differences in the surface morphology between all groups (only some examples of scans 1 x $1 \mu \mathrm{m}$ are shown).

Table 2. Mean values for $\mathrm{S}_{\mathrm{a}}$ for $\mu \mathrm{m}$ (standard deviation) for topographical analyses of discs with AFM in 3 different magnifications and P-values for one-way ANOVA comparisons

\begin{tabular}{c|c|c|c|c}
\hline $\begin{array}{c}\text { Concentration of } \\
\mathbf{1 . 2 5}-(\mathbf{O H})_{\mathbf{2}} \mathbf{D}_{\mathbf{3}} \mathbf{( M )}\end{array}$ & $\mathbf{1 0} \mathbf{x} \mathbf{1 0} \boldsymbol{\mu \mathbf { m }}$ & $\mathbf{5} \mathbf{x} \mathbf{\mu m}$ & $\mathbf{1} \mathbf{x} \mathbf{1} \boldsymbol{\mu m}$ & Quantity \\
\hline $\mathbf{0}$ & $0.05(0.006)$ & $0.02(0.005)$ & $0.005(0.0005)$ & 9 \\
\hline $\mathbf{1 0}^{-\mathbf{8}}$ & $0.05(0.006)$ & $0.02(0.0007)$ & $0.007(0.001)$ & 9 \\
\hline $\mathbf{1 0}^{-7}$ & $0.05(0.003)$ & $0.02(0.03)$ & $0.007(0.002)$ & 9 \\
\hline $\mathbf{1 0}^{-6}$ & $0.05(0.005)$ & $0.02(0.005)$ & $0.009(0.003)$ & 9 \\
\hline P-value & 0.932 & 0.938 & 0.126 & \\
\hline
\end{tabular}

Table 3. Mean values for $\mathrm{S}_{\mathrm{dr}}$ in \% (standard deviation) for topographical analyses of discs with AFM in three different magnifications and $\mathrm{P}$-values for one-way ANOVA comparisons

\begin{tabular}{c|c|c|c|c}
\hline $\begin{array}{c}\text { Concentration of } \\
\mathbf{1 . 2 5}-(\mathbf{O H})_{2} \mathbf{D}_{3}(\mathbf{M})\end{array}$ & $\mathbf{1 0} \mathbf{x} \mathbf{1 0} \boldsymbol{\mu m}$ & $\mathbf{5} \times \mathbf{5} \boldsymbol{\mu m}$ & $\mathbf{1} \times \mathbf{1} \boldsymbol{\mu m}$ & Quantity \\
\hline $\mathbf{0}$ & $11.7(1.8)$ & $10.3(4.6)$ & $36.3(48.1)$ & 9 \\
\hline $\mathbf{1 0}^{-8}$ & $11.4(2.9)$ & $10.8(1.6)$ & $46.9(32.1)$ & 9 \\
\hline $\mathbf{1 0}^{-7}$ & $13.4(0.7)$ & $12.3(2.9)$ & $48(48)$ & 9 \\
\hline $\mathbf{1 0}^{-6}$ & $13.3(3.3)$ & $13.9(5)$ & $39.5(24)$ & 9 \\
\hline P-value & 0.65 & 0.66 & 0.978 & \\
\hline
\end{tabular}

Table 4. Mean values for $\mathrm{S}_{\mathrm{ds}}$ in $\mu \mathrm{m}^{-2}$ (standard deviation) for topographical analyses of discs with AFM in three different magnifications and P-values for one-way ANOVA comparisons

\begin{tabular}{c|c|c|c|c}
\hline $\begin{array}{c}\text { Concentration of } \\
\mathbf{1 . 2 5}-(\mathbf{O H})_{\mathbf{2}} \mathbf{D}_{\mathbf{3}}(\mathbf{M})\end{array}$ & $\mathbf{1 0} \mathbf{x} \mathbf{1 0} \boldsymbol{\mu m}$ & $\mathbf{5} \times \mathbf{5} \boldsymbol{\mu m}$ & $\mathbf{1} \mathbf{x} \mathbf{1} \boldsymbol{\mu m}$ & Quantity \\
\hline $\mathbf{0}$ & $12.9(6.4)$ & $33.9(15.6)$ & $2434.6(2111.6)$ & 9 \\
\hline $\mathbf{1 0}^{-8}$ & $15.9(4.1)$ & $49.6(18.9)$ & $2472.6(1327)$ & 9 \\
\hline $\mathbf{1 0}^{-7}$ & $18.6(7.8)$ & $53.2(27.1)$ & $2725.9(888.1)$ & 9 \\
\hline $\mathbf{1 0}^{-6}$ & $13.6(1.6)$ & $39.3(4.3)$ & $2262.2(1677.8)$ & 9 \\
\hline P-value & 0.602 & 0.575 & 0.978 & \\
\hline
\end{tabular}

IMF Control

Figure 1. Descriptive IFM and AFM three-dimensionally reconstructed images of the groups tested in the study. 


\section{Histological evaluation}

The animals recovered without complications and no signs of infection were noted upon clinical examination at any time during the observation period. The mean BIC in percentage was 4.4 (1.9) for the control group $(0 \mathrm{M}), 8.7$ (4.6) for group I $\left(10^{-8} \mathrm{M}\right)$, 8.2 (3.3) for group II $\left(10^{-7} \mathrm{M}\right)$ and 7.4 (3.8) for group III $\left(10^{-6} \mathrm{M}\right)$, respectively. The experimental group

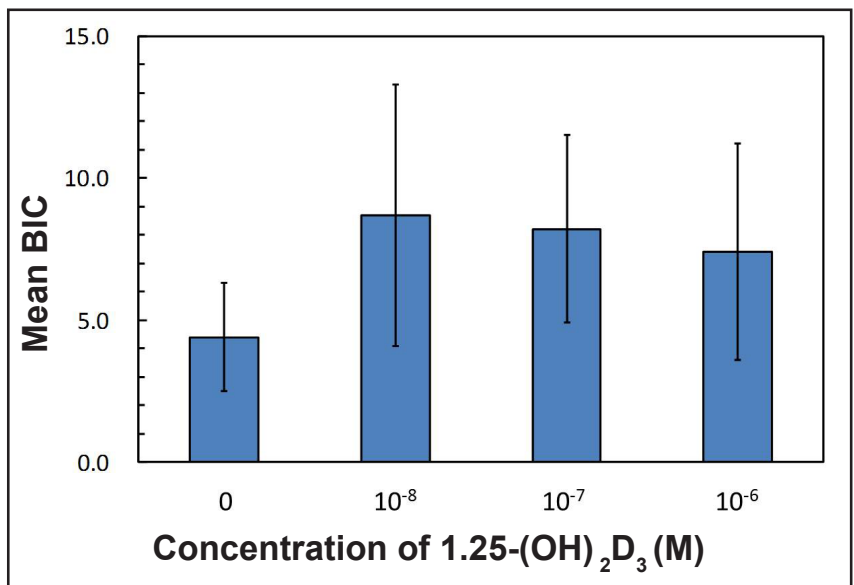

Figure 2. Mean values in percentage (\%) of bone-to-implantcontact (BIC) around the total dental implant for each tested group.

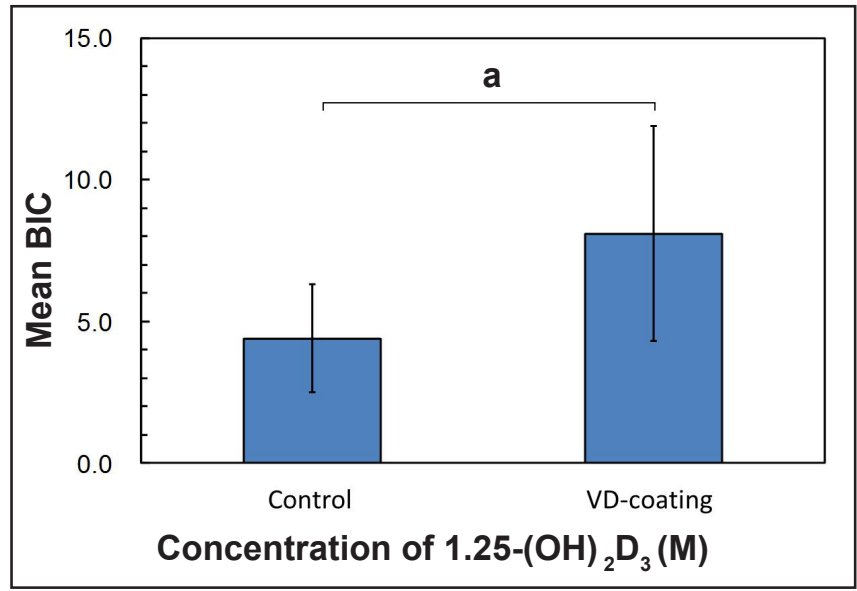

Figure 4. Mean values (non-coating vs. coating) in percentage (\%) of bone-to-implant-contact (BIC) around the total dental implant. aStatistical significance $(\mathrm{P}<0.05)$.

Table 5. Mean values in percentage (standard deviation) for histological analyses and P-values for one-way ANOVA

\begin{tabular}{c|c|c|c}
\hline $\begin{array}{c}\text { Concentration of } \\
\mathbf{1 . 2 5}_{-}(\mathbf{O H})_{\mathbf{2}} \mathbf{D}_{\mathbf{3}} \mathbf{( M )}\end{array}$ & BIC total & NBA total & Quantity \\
\hline $\mathbf{0}$ & $4.4(1.9)$ & $16.7(8)$ & 7 \\
\hline $\mathbf{1 0}^{-8}$ & $8.7(4.6)$ & $16.5(4.2)$ & 7 \\
\hline $\mathbf{1 0}^{-7}$ & $8.2(3.3)$ & $15.4(8.1)$ & 7 \\
\hline $\mathbf{1 0}^{-6}$ & $7.4(3.8)$ & $16.1(11.1)$ & 7 \\
\hline P-value & 0.162 & 0.775 & \\
\hline
\end{tabular}

$\mathrm{BIC}=$ bone-to-implant-contact; $\mathrm{NBA}=$ new bone area. showed a trend toward higher bone contact, however the results were not statistically significant (Figure 2, Table 5). The means for NBA in percentage were 16.7 (8) for the control group, 16.5 (4.2) for group I, 15.4 (8.1) for group II and 16.1 (11.1) for group III, respectively, with no significant differences between each of the groups (Figure 3, Table 5). When the effect of dosage was collapsed and statistically compared to the control, there was a statistically significant effect of the vitamin D coating in BIC $(\mathrm{P}<0.05)$ (Figure 4, Table 6). However, no significant differences were found in NBA $(\mathrm{P}>0.05)$ (Figure 5, Table 6).

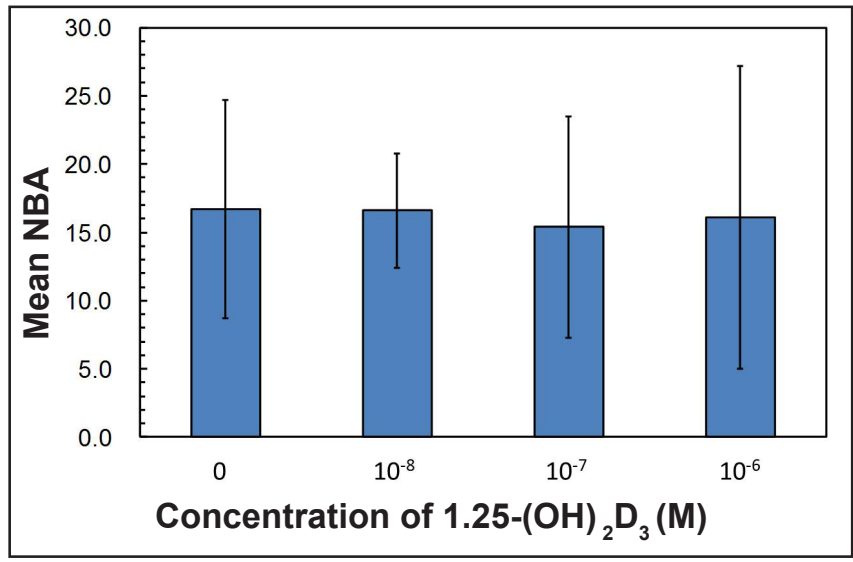

Figure 3. Mean values in percentage (\%) of new bone area (NBA) around the total dental implant for each tested group.

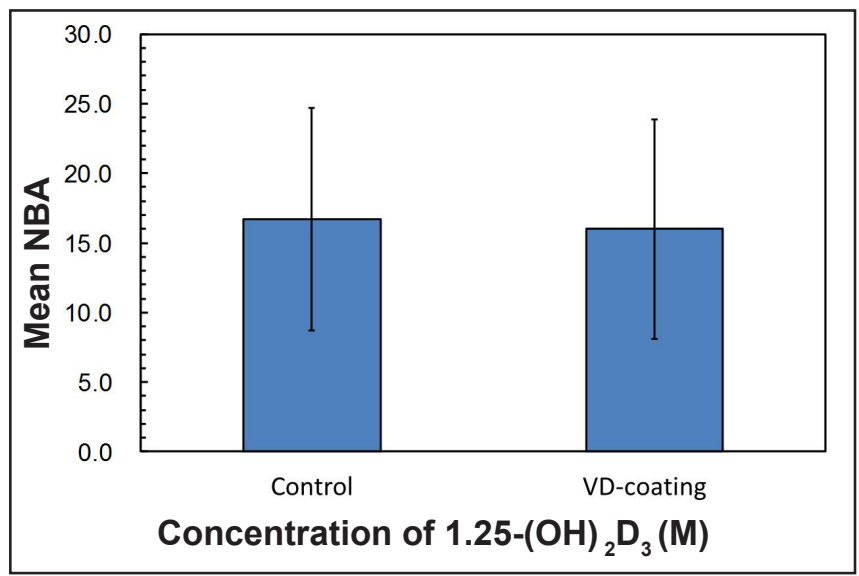

Figure 5. Mean values (non-coating vs. coating) in percentage (\%) of new bone area (NBA) around the total dental implant.

Table 6. Mean values in percentage (standard deviation) on the comparison between control vs coated groups (the effect of dose was collapsed) and P-values for one-way ANOVA

\begin{tabular}{c|c|c|c}
\hline & BIC total & NBA total & Quantity \\
\hline Control & $4.4(1.9)$ & $16.7(8)$ & 7 \\
\hline VD-coating & $8.1(3.8)$ & $16(7.9)$ & 21 \\
\hline P-value & 0.27 & 0.756 & \\
\hline
\end{tabular}

$\mathrm{BIC}=$ bone-to-implant-contact NBA $=$ new bone area. 


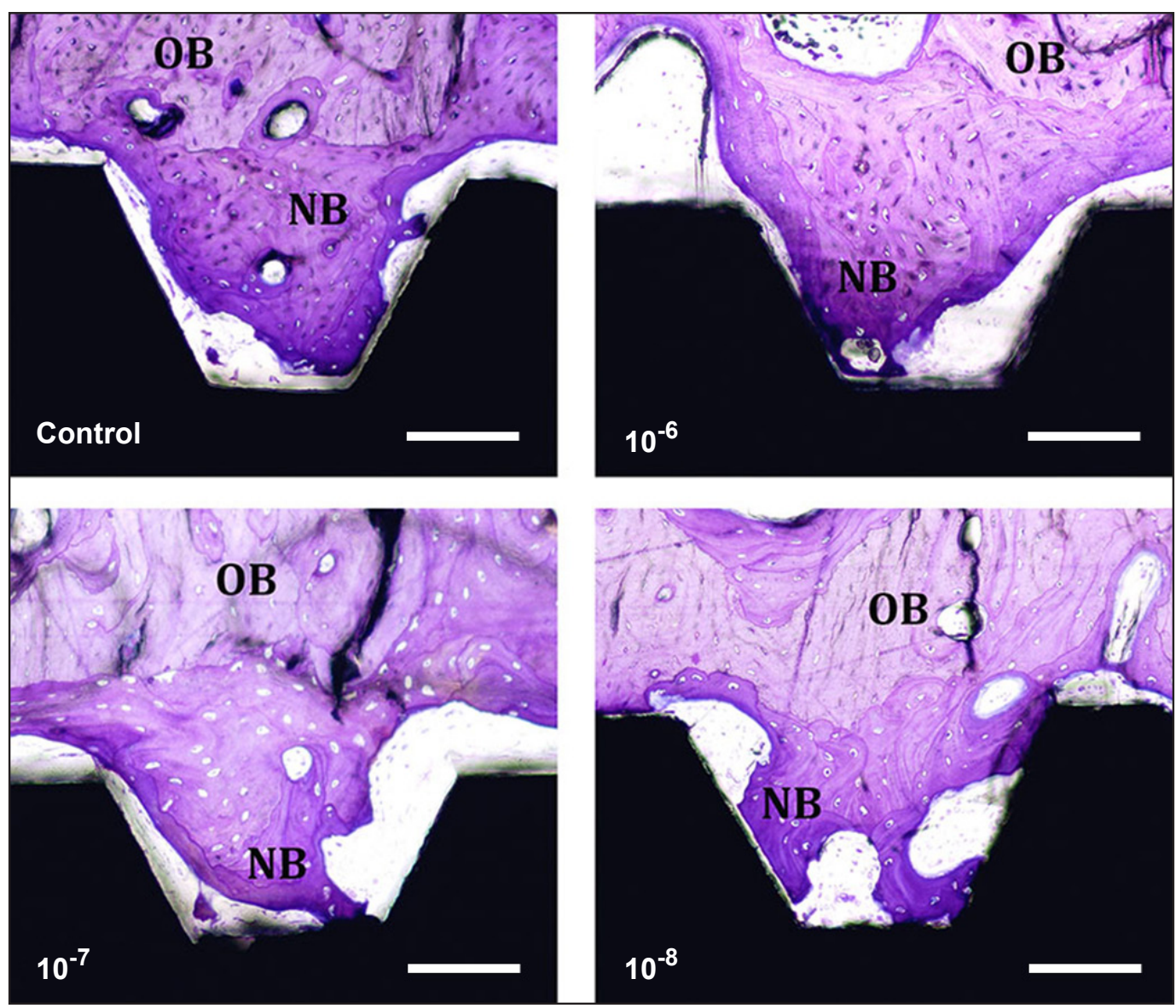

Figure 6. Histological photographs of the bone tissue formed around all tested groups after 6 weeks of implantation. Original magnification $\mathrm{x} 10$, Toluidine blue staining. Scale bar: $100 \mu \mathrm{m} . \mathrm{NB}=$ new bone; $\mathrm{OB}=$ old bone.

Figure 6 illustrates descriptive optical microscope images of the histological section from the uncoated control group and the coated groups. For all groups, newly formed bone was intact to the implant and no signs of inflammation or the presence of multinucleated giant cells were seen.

\section{DISCUSSION}

This study aimed to histologically evaluate the biologic effect of 1.25- $(\mathrm{OH})_{2} \mathrm{D}_{3}$ coated onto implant surfaces. It was hypothesized that the biologic response would be distinct depending on the dosage of $1.25-(\mathrm{OH})_{2} \mathrm{D}_{3}$ applied to the implant surface.

It has been suggested that the optimal $\mathrm{S}$ value to obtain good bone response is between $1-1.5 \mu \mathrm{m}$, which is the so-called moderately roughened implant surface [23]. While surface roughness has been shown to affect bone response we utilized a smooth turned metal surface to examine the effect of the $1.25-(\mathrm{OH})_{2} \mathrm{D}_{3}$ coating without underlying implant roughness. This methodology has been used in other studies experimentally attempting to determine the effect of various protein or calcium phosphate coatings on the bone-to-implant response $[\underline{8}, \underline{24}, \underline{25}]$. While the surface roughness values between all groups tested were similar, there were significant differences in the density of summits $\left(\mathrm{S}_{\mathrm{ds}}\right)$ between groups $(\mathrm{P}=0.049)$. This significance is probably due to the different $1.25-(\mathrm{OH})_{2} \mathrm{D}_{3}$ coating concentrations, as the test groups showed higher mean values than control group (Table 1), thus the coatings may have resulted in changes to the surface topography. Interestingly, the AFM measurements demonstrated no statistical differences between all groups tested in the nanometer length scale (Table 2 - 4), despite each group presenting different qualitative topographical features as seen in the three-dimensional reconstructed images. Overall, the interferometer and AFM results indicate that coatings of $1.25-(\mathrm{OH})_{2} \mathrm{D}_{3}$ slightly altered the surface topography in a dose dependent manner, which may have influenced the host biological responses.

Previous studies have shown that vitamin D is dose dependent in serum [17,21] but it should also be noted that vitamin $\mathrm{D}$ also has a bone resorbing effect, especially with high therapeutic doses [17]. Thus, the selection of the optimal concentration must be determined based on further evidence. 
Moreover, it remains to be identified how much coating agent remains on the implant because the specimens were coated with the traditionally utilized dip coating, furthermore, turned surface implants were the base substrates. It is thought that one reason for the small differences between all groups in terms of histomorphometry was that the dip coating on the turned surface did not assure stable protein adsorption to the surface and the $1.25-(\mathrm{OH})_{2} \mathrm{D}_{3}$ simply remained after air drying. Thus, naturally, the release of the protein was a rapid process, which could not provide a sufficient bone forming effect. In future studies, the amount of protein adsorption to a modified textured surface, and its release rate should be determined in order to obtain the optimal surface for protein incorporation.

This study intended to investigate a possibly bioactive implant surface with the use of different $1.25-(\mathrm{OH})_{2} \mathrm{D}_{3}$ concentrations. Although there was a tendency for the $1.25-(\mathrm{OH})_{2} \mathrm{D}_{3}$ coated implants to show better bone responses, the results were not significant. Thus, an implant surface that can sustain the $1.25-(\mathrm{OH})_{2} \mathrm{D}_{3}$ over a long period of time should be considered.

\section{CONCLUSIONS}

The current study demonstrated that there may be dose dependent biologic effects of the $1.25-(\mathrm{OH})_{2} \mathrm{D}_{3}$ in vivo, however the differences were insignificant within the limitation of the study.

\section{ACKNOWLEDGMENTS AND DISCLOSURE STATEMENTS}

The authors declare no conflict of interests.

\section{REFERENCES}

1. Wennerberg A, Albrektsson T. On implant surfaces: a review of current knowledge and opinions. Int J Oral Maxillofac Implants. 2010 Jan-Feb;25(1):63-74. Review. [Medline: 20209188]

2. Bougas K, Jimbo R, Vandeweghe S, Tovar N, Baldassarri M, Alenezi A, Janal M, Coelho PG, Wennerberg A. In Vivo Evaluation of a Novel Implant Coating Agent: Laminin-1. Clin Implant Dent Relat Res. 2013 Jan 11. [Epub ahead of print] [Medline: 23311639] [doi: 10.1111/cid.12037]

3. Park JW, Lee SG, Choi BJ, Suh JY. Effects of a cell adhesion molecule coating on the blasted surface of titanium implants on bone healing in the rabbit femur. Int J Oral Maxillofac Implants. 2007 Jul-Aug;22(4):533-41. [Medline: 17929513]

4. Schwartz-Filho HO, Bougas K, Coelho PG, Xue Y, Hayashi M, Faeda RS, Marcantonio RA, Ono D, Kobayashi F, Mustafa K, Wennerberg A, Jimbo R. The effect of laminin-1-doped nanoroughened implant surfaces: gene expression and morphological evaluation. Int J Biomater. 2012;2012:305638. Epub 2012 Dec 12. [Medline: 23304151] [PMC free article: PMC3530800] [doi: 10.1155/2012/305638]

5. Sul YT, Kwon DH, Kang BS, Oh SJ, Johansson C. Experimental evidence for interfacial biochemical bonding in osseointegrated titanium implants. Clin Oral Implants Res. 2013 Aug;24 Suppl A100:8-19. Epub 2011 Nov 14. [Medline: 22093014] [doi: 10.1111/j.1600-0501.2011.02355.x]

6. Sul YT, Johansson C, Albrektsson T. A novel in vivo method for quantifying the interfacial biochemical bond strength of bone implants. J R Soc Interface. 2010 Jan 6;7(42):81-90. Epub 2009 Apr 15. [Medline: 19369221] [PMC free article: PMC2839374] [doi: 10.1098/rsif.2009.0060]

7. Franke Stenport V, Johansson CB, Sawase T, Yamasaki Y, Oida S. FGF-4 and titanium implants: a pilot study in rabbit bone. Clin Oral Implants Res. 2003 Jun;14(3):363-8. [Medline: 12755787] [doi: 10.1034/j.1600-0501.2003.00846.X]

8. Jimbo R, Sawase T, Shibata Y, Hirata K, Hishikawa Y, Tanaka Y, Bessho K, Ikeda T, Atsuta M. Enhanced osseointegration by the chemotactic activity of plasma fibronectin for cellular fibronectin positive cells. Biomaterials. 2007 Aug;28(24):3469-77. Epub 2007 May 3. [Medline: 17512051] [doi: 10.1016/j.biomaterials.2007.04.029]

9. Matsuura T, Hosokawa R, Okamoto K, Kimoto T, Akagawa Y. Diverse mechanisms of osteoblast spreading on hydroxyapatite and titanium. Biomaterials. 2000 Jun;21(11):1121-7. [Medline: 10817264] [doi: 10.1016/S0142-9612(99)00264-1]

10. Li YC, Amling M, Pirro AE, Priemel M, Meuse J, Baron R, Delling G, Demay MB. Normalization of mineral ion homeostasis by dietary means prevents hyperparathyroidism, rickets, and osteomalacia, but not alopecia in vitamin D receptor-ablated mice. Endocrinology. 1998 Oct;139(10):4391-6. [Medline: 9751523]

11. Stoffels K, Overbergh L, Giulietti A, Verlinden L, Bouillon R, Mathieu C. Immune regulation of 25-hydroxyvitaminD3-1alpha-hydroxylase in human monocytes. J Bone Miner Res. 2006 Jan;21(1):37-47. Epub 2005 Sep 19. [Medline: 16355272] [doi: 10.1359/JBMR.050908]

12. Nemere I, Garbi N, Hammerling G, Hintze KJ. Role of the 1,25D3-MARRS receptor in the 1,25(OH)2D3-stimulated uptake of calcium and phosphate in intestinal cells. Steroids. 2012 Aug;77(10):897-902. Epub 2012 Apr 21. [Medline: 22546984] [doi: 10.1016/j.steroids.2012.04.002] 
13. Nagaoka H, Mochida Y, Atsawasuwan P, Kaku M, Kondoh T, Yamauchi M. 1,25(OH)2D3 regulates collagen quality in an osteoblastic cell culture system. Biochem Biophys Res Commun. 2008 Dec 12;377(2):674-8. Epub 2008 Oct 18. [Medline: 18930711] [doi: 10.1016/j.bbrc.2008.10.036]

14. St-Arnaud R. The direct role of vitamin D on bone homeostasis. Arch Biochem Biophys. 2008 May 15;473(2):225-30. Epub 2008 Apr 6. Review. [Medline: 18424254] [doi: 10.1016/j.abb.2008.03.038]

15. Kelly J, Lin A, Wang CJ, Park S, Nishimura I. Vitamin D and bone physiology: demonstration of vitamin D deficiency in an implant osseointegration rat model. J Prosthodont. 2009 Aug;18(6):473-8. Epub 2009 Mar 26. [Medline: 19486459] [doi: 10.1111/j.1532-849X.2009.00446.x]

16. Masuyama R, Stockmans I, Torrekens S, Van Looveren R, Maes C, Carmeliet P, Bouillon R, Carmeliet G. Vitamin D receptor in chondrocytes promotes osteoclastogenesis and regulates FGF23 production in osteoblasts. J Clin Invest. 2006 Dec;116(12):3150-9. Epub 2006 Nov 9. [Medline: 17099775] [PMC free article: PMC1635166] [doi: 10.1172/JCI29463]

17. Suda T, Takahashi F, Takahashi N. Bone effects of vitamin D - Discrepancies between in vivo and in vitro studies. Arch Biochem Biophys. 2012 Jul 1;523(1):22-9. Epub 2011 Nov 15. Review. [Medline: 22107950] [doi: 10.1016/j.abb.2011.11.011]

18. Tang X, Meng H. Osteogenic induction and 1,25-dihydroxyvitamin D3 oppositely regulate the proliferation and expression of RANKL and the vitamin D receptor of human periodontal ligament cells. Arch Oral Biol. 2009 Jul;54(7):625-33. Epub 2009 May 22. [Medline: 19464673] [doi: 10.1016/j.archoralbio.2009.04.009]

19. Spagnoli DB, Marx RE. Dental implants and the use of rhBMP-2. Oral Maxillofac Surg Clin North Am. 2011 May;23(2):347-61, vii. Review. [Medline: 21492806] [doi: 10.1016/j.coms.2011.02.003]

20. Huang Y, Ishizuka T, Miura A, Kajita K, Ishizawa M, Kimura M, Yamamoto Y, Kawai Y, Morita H, Uno Y, Yasuda K. Effect of 1 alpha,25-dihydroxy vitamin D3 and vitamin $\mathrm{E}$ on insulin-induced glucose uptake in rat adipocytes. Diabetes Res Clin Pract. 2002 Mar;55(3):175-83. [Medline: 11850093] [doi: 10.1016/S0168-8227(01)00324-2]

21. Song I, Kim BS, Kim CS, Im GI. Effects of BMP-2 and vitamin D3 on the osteogenic differentiation of adipose stem cells. Biochem Biophys Res Commun. 2011 Apr 29;408(1):126-31. doi: 10.1016/j.bbrc.2011.03.135. Epub 2011 Apr 2. [Medline: 21463608] [doi: 10.1016/j.bbrc.2011.03.135]

22. Wennerberg A, Albrektsson T, Lausmaa J. Torque and histomorphometric evaluation of c.p. titanium screws blasted with 25- and 75-microns-sized particles of A12O3. J Biomed Mater Res. 1996 Feb;30(2):251-60. [Medline: 9019491$]$ [doi: 10.1002/(SICI)1097-4636(199602)30:2<251::AID-JBM16>3.0.CO;2-P]

23. Albrektsson T, Wennerberg A. Oral implant surfaces: Part 1--review focusing on topographic and chemical properties of different surfaces and in vivo responses to them. Int J Prosthodont. 2004 Sep-Oct;17(5):536-43. [Medline: 15543910]

24. Bougas K, Jimbo R, Vandeweghe S, Hayashi M, Bryington M, Kozai Y, Schwartz-Filho HO, Tovar N, Adolfsson E, Ono D, Coelho PG, Wennerberg A. Bone apposition to laminin-1 coated implants: histologic and 3D evaluation. Int J Oral Maxillofac Surg. 2013 May;42(5):677-82. Epub 2012 Dec 8. [Medline: 23228694] [doi: 10.1016/j.ijom.2012.11.008]

25. Jimbo R, Coelho PG, Vandeweghe S, Schwartz-Filho HO, Hayashi M, Ono D, Andersson M, Wennerberg A. Histological and three-dimensional evaluation of osseointegration to nanostructured calcium phosphate-coated implants. Acta Biomater. 2011 Dec;7(12):4229-34. Epub 2011 Jul 21. [Medline: 21816237] [doi: 10.1016/j.actbio.2011.07.017]

\section{To cite this article:}

Naito Y, Jimbo R, Bryington MS, Vandeweghe S, Chrcanovic BR, Tovar N, Ichikawa T, Coelho PG, Wennerberg A. The Influence of 1 $\alpha .25$-Dihydroxyvitamin D3 Coating on Implant Osseointegration in the Rabbit Tibia.

J Oral Maxillofac Res 2014;5(3):e3

URL: http://www.ejomr.org/JOMR/archives/2014/3/e3/v5n3e3ht.pdf

doi: $10.5037 /$ jomr.2014.5303

Copyright (C) Naito Y, Jimbo R, Bryington MS, Vandeweghe S, Chrcanovic BR, Tovar N, Ichikawa T, Coelho PG, Wennerberg A. Published in the JOURNAL OF ORAL \& MAXILLOFACIAL RESEARCH (http://www.ejomr.org), 1 October 2014.

This is an open-access article, first published in the JOURNAL OF ORAL \& MAXILLOFACIAL RESEARCH, distributed under the terms of the Creative Commons Attribution-Noncommercial-No Derivative Works 3.0 Unported License, which permits unrestricted non-commercial use, distribution, and reproduction in any medium, provided the original work and is properly cited. The copyright, license information and link to the original publication on (http://www.ejomr.org) must be included. 